\title{
The Ideology of a Nation of Immigrants and the Issue of Employment in Aviva Chomsky's "They Take our Jobs"! And 20 Other Myths about Immigration.
}

\author{
Emmanuel Ngor NDIAYE
}

\begin{abstract}
This study explores the postulate studied in Aviva Chomsky's "They Take our Jobs"! And 20 Other Mythsabout Immigration. It examines the assumptions and arguments that fuel the public discourse about U.S. immigration. As noted by Chomsky, those arguments are based on myths that should be deconstrued to better understand the rationale behind the anti-immigrant rhetoric which is reflected by stereotypes such as immigrants take American jobs, drain down wages, or represent a threat to the social order and national security. On the basis of these arguments and information drawn from diverse sources, we have shown how from a nation of immigrants, America has become a country where immigrants take American jobs. Thus, the idea of the nation of immigrants refers specifically to immigrants of European ancestry, in particular those from northwestern Europe. The latter, also known as the WASP, represent the American mainstream culture and their hegemony is widespread to the point of influencing other sectors where decision-making processes echo the legacy, the values and expectations of the white community. Starting from these arguments, it can be stated that Anglo-Saxonism is fundamentally based on the domination of other communities and the institutions and ideologies of the United States reflect this reality.
\end{abstract}

Keywords: Anglo-Saxons, Assumptions, Hegemony, Immigration, Jobs, Labor-force, Myths, Stereotypes, Social-order, Supremacy.

\section{Introduction}

The United States is commonly known as a nation of immigrants thanks to the different waves of immigrants who, as history suggests, have contributed to a particular set of abilities and traits that helped shape the American nation. Building upon the latter point of view, it should be admitted that immigrants have always contributed to the economic, cultural, and social development of the country. Nevertheless, despite their contributions that are noticeable in various sectors of activities, there is no doubt that immigrants are nowadays associated with criminals, terrorists, and other threats, hence the arbitrary need for American authorities to envision new restrictive immigration policies.

In other respects, according to anti-immigrant parties, in addition to representing an economic burden, immigrants threaten the national security and the social order of the USA. For a long time, such points of view have been asserted by many people throughout the country. However, whatever the attitudes that the latter may have toward immigrants, it should be noted that the public opinion about U.S. immigration varies a lot in the society.

With regards to this perspective, it is important to point out that the issue of U.S. immigration has generated controversy both within and outside the United States. On the one hand, this controversy can be addressed from an economic approach in which employers and legislators are involved. On the other hand, the controversy about the American immigration debate has cultural, social, and political orientations. Just like the economic approach, the general opinions are based on ideas according to which immigrants represent a social threat to Americans' employments.

Nevertheless, it is quite obvious that - as a nation of immigrants - America owes its prosperity to immigrants. That is in this sense that John F. Kennedy argues that "this nation was founded by men of many 
nations and backgrounds" (Kennedy, 1964). In Survivances de la doctrine du puritanisme dans l'Amérique moderne (2015), Louis Mendy develops the issue of immigration which, as he argues, "...remains one the most striking survivors of puritanism" (Mendy, 319). Thus, for several centuries, immigrants have represented either voluntarily or involuntarily a cheap labor that helped build the American economy. Today, owing to the global economic restructuring, the need for foreign workers and other diverse incentives, the flux of American immigration has widely increased to the point of becoming a confrontational issue both within and outside the country. Thus, many specialists among whom historians, politicians, economists, psychologists, sociologists, but also journalists and literary writers have shown much interest in it.

In that vein, American academic, historian, and activist Aviva Chomsky wrote a groundbreaking book which sheds light on this issue that has long been misunderstood by some people. Born on $20^{\text {th }}$ April 1957 , she is the eldest daughter of the linguists Noam and Carol Chomsky and early in her life she has been interested in migrant workers, immigration, labor history, and social movements. In "They Take our Jobs!" And 20 Other Myths about Immigration (2007), Chomsky invites us to better examine the immigration debate which, as she states, is based on myths that should be challenged and dismantled. Unlike the wrong assumptions and general misinformation that are commonly advanced, Chomsky's work helps us better understand the immigration debate and the rationale behind the prejudices and stereotypes that are used to describe immigrants.

To this regard, drawing upon her empirical analysis and arguments, we are going to discuss how she brings to light the misconceptions about immigration and the ideas according to which immigrants take American jobs, which leads Arthur Schlesinger to worry about the "disuniting of America" (Chomsky, XV). As Chomsky mentions throughout her work, those arguments are based on myths and anti-immigrant sentiments that serve a purpose for a more restrictive immigration policy which is one of the topical issues of the Trump administration. In this sense, when examining her study, our purpose is to show how from a nation of immigrants, America has become a nation where immigrants take American jobs. As such, it is necessary to reassess the concept of a nation of immigrants and this raises the following questions: what is meant by American jobs? Do jobs have a national identity?

To shed light on these issues, the first section expounds on the idea of Anglo-Saxonism which makes America a white Anglo-Saxon country. What is interesting to mention here is that, even though the United States is historically known as a nation of immigrants, it defines itself as a white Anglo-Saxon country; in other words, a country with an English-oriented culture. In the second one, the analysis focuses on the impact of global economic restructuring on U.S. economy. As above mentioned, global economic changes have impacted on U.S. economy hence the need for foreign workers or even the outsourcing of some U.S. companies for a cheap labor. In the third and last section of this study, information and explanations about U.S. foreign policy and unilateralism are analyzed to show how America itself contributes to the increased flux of immigration through different pull and push factors.

\section{The United States As A White Anglo-Saxon Country}

In Emma Lazarus' poem "The New Colossus", questions about the ideology of the nation of immigrants are developed to show how America welcomes people from everywhere and who are looking for a place where they can pursue their dream. However, despite this historical definition of America, we should bear in mind that whatever its cultural diversity, the dominant culture of the USA is that of the White Anglo-Saxon Protestants. In the words of Sociologists William Thomas and Joseph Hickey,

The term WASP has many meanings. In sociology it reflects that segment of the U.S. population that founded the nation and traced their heritages to (...) Northwestern Europe. The term (...) has become more inclusive. To many people, WASP now includes most white people who are not (...) members of any minority groups. (Thomas and Hickey, web)

To this sociological definition of the term WASP, we can also add the economic approach of the concept. In other terms, being the mainstream culture, the WASP are almost represented in all sectors of activities and this is what explains white hegemony over minorities. 


\section{I.1. White Hegemony over Minority Communities}

The United States, unlike any other country, is a multicultural country due to the diversity of its population which is composed of various ethnic groups. Nonetheless, despite this multiculturalism and the ideas based on the belief that oppressed and poverty-stricken people are welcomed in America, it is worth recalling that some ethnic groups, referred to as minorities, often face racial prejudices. Those communities include the African Americans, Chinese, Mexicans, and Japanese etc. Immigrants are widely represented and are also subjected to discrimination, and other stereotypes such as they take American jobs, they are a drain on the American economy or even contribute to the general poverty and inequality. Reacting to such misconceptions, Aviva Chomsky wrote "They take our Jobs!" And 20 Other Myths about Immigration which deconstructs the way people perceive the U.S. economic and immigration history. As she notes,

Immigrants are blamed of causing or exacerbating a wide variety of economic ills, from unemployment to law wages to the underfunding of government services... "Immigrants take American jobs" is one of the most common arguments brandished to justify the need for a restrictive immigration policy. There are two main fallacies in the argument. They are fallacies that serve a purpose. The first fallacy lies in the very concept of "American" jobs. In fact, today's economy is so globally integrated that the idea of jobs having a national identity is practically useless... The second fallacy is closely tied to the first: the notion that immigration and immigrants reduce the number of jobs available to people already in the United States. (Chomsky, pp. 1-3)

Chomsky's concern lies on two main fallacies. First of all, she calls into question the concept of "American" jobs which is worth scrutinizing. Secondly, she recalls that immigration and immigrants reduce the number of jobs available to people already in the United States. By examining both arguments, we may sustain that they reflect our perspective on "the United States as a White Anglo-Saxon country". In other terms, by "American" jobs, we understand jobs that belong to or should be held by a specific group of Americans who are white Americans. The second argument echoes the need for a restrictive immigration policy.

As indicated earlier, the Anglo-Saxons play an important role in almost all domains ranging from the cultural, social, and economic to the political one. Without any doubt, that is for such a reason that they seek to spread their hegemony over the minorities, which boils down to preserving white dominance and racial inequality. Here, there is a parallel between racial dominance and economic dominance; consequently, the upper race would certainly control the economy to better dominate the other races and avoid being overwhelmed by them.

In fact, white hegemony results also on the marginalization of minorities, and particularly black minorities. To this point, we can refer to Haitian immigrants who-while other immigrants or refugees including Cubans were warmly welcomed-were discriminated at the same time. Regarding this preferential treatment of Cubans over Haitians, Chomsky mentions among other reasons the following:

Cuban immigrants arriving through the Mariel Boatlift were universally accepted as political refugees, while Haitians fleeing the Duvalier dictatorship at the same moment were denied refugee status... Still more pathetic were those black bodies washing ashore Florida's pristine beaches when their craft did not make it. (Chomsky, 67)

The preferential treatment has created ways for exclusion and exploitation as well. For example, when it comes to immigrants, the majority is associated with undocumented immigrants who are deprived of rights and represent a cheap labor. Their recruitment, therefore, has long been prohibited by U.S. laws among which the 1986 Immigration Reform and Control Act (IRCA) which is responsible for penalizing employers who hire unauthorized workers.

In some respects, their continuous increasing number and recruitment are what have given birth to the arguments and stereotypes that are used to describe them. In addition to these arguments which are both socio-economic and political, other cultural arguments can be added to the debate about U.S. immigration. In this regard, as the mainstream culture, the White Anglo-Saxons seek to assimilate other communities to their customs and value the idea of an English-oriented culture. 


\section{I.2. The Spirit of an English-oriented Culture}

Along with other cultural aspects, language is an aspect that helps identify the members of a specific ethnic group. However, with respect to the American context, we have earlier observed that America is a multicultural and multilingual country. Thus, in order to respond to the needs related to language barriers, English has been considered the common language through which the different communities can communicate and understand with each other. Regardless of the use of English as a common language, many people including immigrants, refugees and other minorities find it difficult to communicate in that language and they naturally face communication barriers. In the field of education, for instance, the problem has been noted and that is what James Crawford, in Language Loyalties: A Source Book on the Official English Controversy, addresses in these terms:

It would be problematic enough if all limited-English-Proficiency (LEP) students spoke the same minority language. But with immigration on the rise, as many as eighty languages are represented in some school districts, exacerbating the difficulties of recruiting qualified teachers, assessing student skills, and communicating with parents. Besides the language barrier, children from immigrant and refugee homes are often "at risk" because of poverty, neglect, crime, and other factors that affect school performance. They are more likely to need remedial classes or special education. (Crawford, 313)

Crawford underlines the problem linked to communication barriers in the field of education where children from immigrant and refugee homes are at risk. In other contexts, communication barriers are associated with stereotypes such as immigrants refusing to learn English because they do not want to assimilate or lose their cultural identities and traditional values. Similar to Crawford's analysis on the issue of language in education, Chomsky provides information in the chapter entitled "Today's Immigrants are not learning English, and Bilingual Education just adds to the Problem”. As she writes,

The long waiting lists for available ESL (English as a Second Language) classes and the overwhelming trend for English to predominate among the second and third generations of immigrants from Latin America belie the common belief that new immigrants are reluctant to learn English. In many ways, the language patterns of today's immigrants are similar to those of earlier generations: older immigrants find learning the new language extremely difficult, and sometimes unnecessary, while the younger generation quickly realizes that English is essential and becomes fluent rapidly. By the third generation, the language of the immigrant's homeland tends to be lost. (Chomsky, 110)

What Chomsky retraces in this excerpt echoes the spirit of monolingualism and Americanization which opposes that of multilingualism in schools. Of considerable importance to note here is that, the idea of English monolingualism serves a purpose for a restrictive immigration policy. In another sense, while some people advocate that immigrants do not want to learn English, others consider learning English as a method to preserve white domination over the minority communities that will end up abandoning their languages, "At the same time, anti-foreign (and especially anti-German) propaganda and Americanization campaigns created further pressures for immigrants to abandon their native languages”. (Chomsky, 111)

To a certain extent, the domination of English over other languages has to do with propaganda, cultural domination and white supremacy. That is why, in 1917, the Test Literacy Act, the first national language restriction on immigration, was passed to limit the admission of foreign workers from non-English speaking countries. In the same vein, the spirit of valuing an English-oriented culture was observed in 1751 when Benjamin Franklin expressed an alarm over the Pennsylvania Germans' alleged refusal to speak English:

Why should the Palatine boors be suffered to swarm into our settlements, and, by herding together establish their language and manners to the exclusion of ours? Why should Pennsylvania, founded by the English, become a colony of aliens, who will shortly be so numerous to Germanize us, instead of our Anglifying them, and will never adopt our language or customs, any more than they can acquire our complexion. (Daniels, pp. 109-110) 
The concern raised by Benjamin Franklin can be associated to the same arguments that are evoked today and according to which immigrants refuse to learn English. Despite those beliefs, it is clear that even mastering or learning English does not help everybody mostly when those people are victim of racial prejudices. As regards this situation which is recurrent, Chomsky advocates that:

"But new immigrants also become aware that learning to speak English will not resolve the problems of race. Native Americans and African Americans are native speakers of English-but this has not helped them to assimilate into a U.S. society that still in many ways defines itself as white" (Chomsky, 108)

Considering the arguments developed in the past as well as in the present, we can suggest that the idea of valuing the English-oriented culture does not only have cultural orientations but also socio-economic and political ones in order to maintain white supremacy. Thus, the historian and philosopher John Fisk mentions the English nature of the United States, which reflects how the country has come into existence by means of an English conquest. Nevertheless, despite the English nature of the country, globalization drives migration and it is in this way that there is a link between global economic changes and the U.S. economy.

\section{Global Economic Restructuring And U.S. Economy}

In most cases, the public discourse and arguments about U.S. immigration have to do with the effects of immigration on the American economy. However, since immigrants are very often economic immigrants, there are assumptions or beliefs that sustain that they take American jobs, compete with the low skilled workers, and drive down wages, which Chomsky illustrates in her second myth.

Despite these above-mentioned beliefs, we should observe that globalization drives migration and that the U.S. economy needs both native-born citizens and foreign workers. From another angle, the U.S. economy functions in a global economy and for this reason employers need foreign labor force hence the need for immigrants or the necessity to outsource their companies in some countries where they hope to find a cheap labor to lower their expenses.

\section{II.1. The Outsourcing of Some U.S. Companies for Cheap Labor, Low Expenses and Taxes}

By contrast to the misconceptions and stereotypes that are commonly used to examine the relationship between American immigration and economy, research has shown that the issue is more complex than just the mere presence of immigrants in the United States. From an economic perspective, global economic changes have considerable impacts on the issue of immigration. Consequently, those changes also explain the reason why employers outsource their industries to lower their expenses:

In many industries, employers seek to reduce costs by employing the poorest, most vulnerable people. They do this by moving to parts of the world where poverty and inequality create a vulnerable labor force, and supporting policies that create poverty and inequality at homeincluding immigration policies that keep immigrants coming, and keep them vulnerable. (Chomsky, 3)

Not only does the outsourcing of some companies to other countries have consequences on the United States owing to the fact of not offering jobs to people already in America, but also on the countries where they outsource. As a case in point, we can highlight the exploitation of workers who are not well paid. Those vulnerable workers, as Chomsky qualifies them, experience a situation that hinders their economic advancement which explains their migration for better economic and living conditions.

In another context, the outsourcing of U.S. companies contribute to the flux of immigration given that, in some cases, those companies tend to replace workers by others while creating a competition and a system that favors inequality. To put it differently, workers are too often individuals, with no rights, whose concerns and claims are neglected by policies that support the rights of employers who pretend to offer jobs to unemployed and poor people. As a response to this situation, those workers in outsourced industries end up moving to places where they hope to improve their working conditions. 
This situation has, therefore, long driven immigrants to the United States to the point of victimizing them since, regardless of the opportunities that America offers, the growing number of immigrants - among whom authorized, unauthorized ones, and refugees - has been considered a threat to the social order and national security. This alarming situation is raised in an article "The United States is Already Overpopulated" by the Federation for American Immigration Reform:

The American Dream simply cannot be conveyed undiminished to the next generation if we grow to a nation of 500 million residents, let alone a billion or more. It is rooted in the limits of the land's abundance - and that abundance is being diminished by unsustainable population growth. Americans must now decide what heritage to bequeath to the next generation. A larger population will deprive our children (and ourselves) of the enjoyment of open spaces, biodiversity, and a clean environment and it will jeopardize their standard of living. The time has come for Congress to adopt a population policy that respects the realities governing our environment and quality of life. (FAIR, 2009)

Even though we cannot deny the strong presence of immigrants in America, we should recognize that this is, to a certain extent, related to American presence in other countries where it operates economically, culturally, or politically through different contexts that represent incentives for individuals residing in those countries. Based on the political aspect of this presence, it is worth acknowledging that this situation helps create policies that foster migration and the access of immigrants in the informal economy.

\section{II.2. Immigrants and the Informal Economy}

The relationship between immigrants and U.S. informal sector has long been the subject matter of a diverse literature. In recent years, this issue is associated with discourses such as immigrants compete with the low skilled native-born workers whereas other advocates, in particular employers in this sector, sustain that by contrast to foreign workers, native-born workers are not willing to work in the informal sector. In A Primer on U.S. Immigration in a Global Economy (2006), Judith Gans argues that,

Questions about impacts on wages, economic growth, and economic output are often raised in relation to immigration. Competing claims are made, for example, that immigrants do jobs that "Americans won't do" in contrast to the claim that immigrants take "American" jobs and reduce wages. (Gans, 5)

Regardless of the multifaceted perspectives, it is important to note that whatever the rationale behind the hiring of immigrants in the informal sector, employers seek to lower their costs. Furthermore, given that most immigrants in this sector are often unauthorized workers with no legal rights, we can suggest that it becomes easier for some employers to hire them. This is, therefore, exacerbated by the poverty and inequality which immigrants experience mostly when they are undocumented. As a result, businesses resort to such workers who, despite being vulnerable, represent high profits:

Inequality helps them keep costs down in several ways. First, when workers are poor and lack legal protections, they are more willing to work long hours for low wages. So businesses benefit when there exists a pool of workers without economic or legal recourse. This is one of the reasons why early industries relied on immigrant workers; why agriculture in the United States has used slavery, guest workers, and immigrants; and why businesses tend to oppose restrictions on immigration today. (Chomsky, 13)

The strong presence and need of immigrants in the U.S. informal economy explains the reason why businesses vie against the policies that seek to restrict immigration. Accordingly, when compared to nativeborn workers who are citizens that have benefits which may include health insurance, sick leave, workers' compensation or vacation time, immigrants are just used to fill jobs that are considered dead end jobs because, "First, the dollar is worth more in the home country than it is in the United States" (Chomsky, 15). In "Hardhats: Construction Workers, Manliness, and the 1970 Pro-War Demonstrations", Joshua B. Freeman raises questions about the informal sector as follows:

One place to look is the danger of construction work, a central theme of Christ in Concrete and almost all other writing about the building trade... In fact, many construction workers were semi- 
itinerant, living long stretches away from their families. Second, because construction jobs were of limited duration, informal work groups had to be continually created. (Freeman, 725-744)

By examining the title of the above article, we understand the risk that exists in the construction industry just as is the case in other informal jobs where immigrants are overrepresented. As Chomsky writes, "Immigrants are willing to accept conditions abroad that they would never accept at home... Immigrants do jobs that American citizens wouldn't do." (Chomsky, 16). What should be admitted here is that immigrants accept jobs that American citizens would not, because they have no alternative and consider that their situation is worse at home. Admittedly, together with global economic changes, the issue of immigration is also linked to U.S. foreign policy and unilateralism.

\section{U.S. Foreign Policy And Unilateralism}

Throughout the world, American presence is noticed and this happens in different domains including the economy, culture, education, the army, the healthcare system, politics etc. This presence, however, reflects U.S. foreign policy which consists of American imperialism or conquest of the world. With regard to the military context, Chalmers Johnson argues that, "this vast network of American bases on every continent except Antarctica actually constitutes a new form of empire - an empire of bases" (Johnson, 126). In fact, even though it is clear that America invests in some countries through its foreign policy, it seems interesting to highlight that this investment goes along with defending its interests in those countries.

To this regard, in order to comprehend the rationale behind U.S. foreign investment, it is of considerable interest to look at the socioeconomic and political legacy of this phenomenon. In some cases, this investment is often followed by the exploitation of human or natural resources. However, this is what makes the issue of immigration a humanitarian problem that needs a humanitarian response.

\section{III.1. Immigration as a Humanitarian Problem}

The displacement of humans from one place to another has always been motivated by the quest for better opportunities. In addition to the economic pull factors that favor migration, other push factors incite individuals to leave their countries. Among those push factors, the problem of political instability, persecution are very recurrent in that they create a group of people known as refugees in host countries. Like other western countries, the United States hosts many involuntarily immigrants categorized as refugees or asylum seekers. The latter, therefore, are from countries that are affected by war or other sociopolitical or economic problems.

Also important to mention is that many refugees are often from countries where the USA is or has been militarily involved. However, regardless of the violence, the damage and other losses that it has caused in those countries, refugees from those respective countries are not always welcomed in America. To illustrate this perspective, we can draw evidence from an article published by the Center American for Progress where it is stated that:

Syrian immigrants and refugees have frequently been in the news over the past year, and not always in a positive light. President-elect Donald Trump lashed out against Syrians coming to the United States during his campaign, promising a ban on immigration from countries "compromised by terrorism," calling for "extreme vetting" of immigrants from Muslim and Arab nations, and saying of people already granted refugee status who fled Syria, "If I win, they're going back". (Kallick et al., 2016)

Similar to Syrian immigrants, many other immigrants - in particular those from countries identified as being affected by terrorism - are not welcomed in the United States. Others, on the contrary, are not refugees but they are from countries where the American presence has considerable economic or political impacts. As a case in point, we can mention the issue of colonization which has impact on migration. In other words, during the colonial period, colonial powers drained resources from the colonies and, as a result, this situation has created economic disparities between the two, a situation which leads the inhabitants of the former colonies to migrate. 
Not surprisingly, we can suggest that those inhabitants of the former colonies are, today, longing for the resources that have been taken from their countries to the colonial power. Based on the American context, the problem has been observed with Puerto Rican immigrants who are widely present in the United States:

Colonization sets the stage for later migration... Colonization creates cultural ties. It brings people from metropolis (the colonizing power) to the colony and places them in positions of power while destroying local institutions... Colonization almost always brings in structures of cultural and racial inequality, imbuing the institutions of the colony with the idea of the "white man's burden" - the idea that white Europeans are culturally superior. In this respect, Puerto Rico's experience is typical... Is it any surprise that colonial subjects dream of leaving home for the metropolis? (Chomsky, 123)

Along with Mexico, Puerto Rico is among the countries that have most immigrants in the USA. Likewise, the Philippines is another country that sends many immigrants to the United States just because of being a former American colony. In some instances, U.S. foreign policies and military intervention result to global economic disparities which are humanitarian problems that lead to migration. Additionally, training programs and the quest for a qualified labor force are among U.S. policies that drive migration.

\section{III.2. Training Programs and the Quest for a Qualified Labor Force}

Migration is very often justified by either the pull factors in receiving countries or the push factors in sending countries. When it comes to the pull factors, host countries, like the United States, project an image of omnipotence. In other terms, throughout the world, the USA is considered as a land of plenty and Americans as people of plenty. As a consequence, this lure of America as a country of plenty is projected worldwide through attractive programs that are broadcast on digital platforms such as the internet, the TV, the radio and other social networks.

Moreover, another important element of U.S. foreign policy that drives immigrants is the study, exchange, and training programs offered by the U.S. Department of State. Although such programs promote high skilled immigration, it remains true that they may have negative consequences. As a matter of fact, in her study How America Still Welcomes Terrorists, Criminals and Other Foreign Menaces to our Shores, Michelle Maklin raises the problem related to visa overstays among whom some entered the USA legally through the study or exchange programs.

Maklin's concern with regard to visa overstays is that after being legally admitted on tourist or student visas, those individuals refuse to go back at the end of their programs. As such, they end up becoming illegal immigrants who run the risk of arrestation and deportation. In other cases, others pretend to be asylum seekers, which Maklin explains in a section "Game the System: Marriage Fraud, Asylum, or Amnesty" of her first chapter:

Among those who attempted to take advantage of our generosity: Mohdar Mohamed Abdoulah, a former San Diego State University student from Yemen suspected of aiding and befriending at least three of the September 11 hijackers. In May 2000, he filed what federal prosecutors now charge is a false asylum application claiming to be a persecuted minority from Somalia. After his arrest in May 2002, Abdoulah spoke of "the hatred in his heart" for the United States government, and railed that the United States brought "this on themselves," according to federal prosecutors. (Maklin, 12)

Maklin draws our attention to the problem of individuals that have been admitted by generosity and who, in reality, ended up becoming a threat to the country. In like manner, the current immigration debate raises issues linked to exchange or study programs that seek to admit skilled immigrants, particularly those who have knowledge in STEM (Science, Technology, Engineering and Mathematics) domains. Nevertheless, whatever the category of individuals admitted into the USA, it remains to be aware that there will always be arguments and stereotypes that discredit immigration. In his study Heaven's Door: Immigration Policy and the American Economy (1999), George J. Borjas writes:

Immigration, however, does more than just increase the total income accruing to natives. Immigration also induces a substantial redistribution of wealth, away from workers who compete with immigrants and toward employers and other users of immigrant services. Immigration may 
also benefit or harm the United States through what are called externalities... Most of these externalities, however, are hard to measure, and the calculation of their benefit or harm will often be in the eye of the beholder. (Borjas, 13)

Considering Borjas' arguments, it seems crucial to observe that U.S. immigration has both advantages and drawbacks. As such, regardless of the category of immigrants that may be admitted into the USA, there will be supporters and opponents as well. In this respect, as mentioned in previous passages, it is worth recalling that the immigration issue goes beyond what is commonly believed and it has generated the arguments that serve the purpose of stereotyping the immigrants.

\section{Conclusion}

The American immigration debate, even though there are issues that are more pressing or problematic, is a complex issue that has always marked the history of the USA. As such, it is a topical issue in which policymakers, employers, and workers play an integral part in that it has become a global issue that has both internal and external consequences. With respect to the internal consequences, different arguments have shown that one segment of the American public opposes immigration whereas another segment supports it. In this sense, it is a global issue that should be addressed from a global perspective given that globalization drives migration.

Thanks to its historical context as a nation of immigrants, the United States has, throughout its history, welcomed different waves of immigrants who were and are still driven by a number of factors that are socioeconomic, cultural, ideological, and political. Among these factors, economic disparities between sending and receiving countries have been noticed as being the driving force behind migration to the United States which is known to have a robust economy that depends on both native and foreign-born workers. To some extent, the need for a foreign labor force is related to international economic integration that gives employers the choice to resort to either native or foreign workers depending on what category of workers bring them high profits.

Obviously, on the basis of the above analysis, the U.S. immigration debate should be analyzed and understood in the context of globalization instead of being focused on assumptions that discredit immigrants. In other words, the stereotypes and arguments according to which immigrants take American jobs, drain down wages or compete with native workers, are - as Chomsky investigated in her work-based on myths that should be deconstructed for a better understanding of the immigration issue.

In fact, to better understand those arguments and stereotypes used to describe immigrants and immigration, we should refer to ideas on which the United States was founded as a nation of immigrants. Although it is a racially diverse country, we should bear in mind that the immigrants, it refers to as a nation of immigrants, are European immigrants and in particular those from northwestern Europe, better known as the White Anglo-Saxon community who, as previously noted, seeks to spread their hegemony over minority communities to better control the country.

\section{Bibliography}

[1] BORJAS, George J. (1999), Heaven's Door: Immigration Policy and the American Economy, New Jersey: Princeton University Press.

[2] CHOMSKY, Aviva (2007), "They take our Jobs!" And 20 Other Myths about Immigration, Boston: Beacon Press.

[3] CRAWFORD, James (1992), Language Loyalties: A Source Book on the Official English Controversy, Chicago: The University of Chicago Press.

[4] DANIELS, Roger (1990), Coming to America: A History of Immigration and Ethnicity in American Life, Second Edition, Princeton: Visual Education Corporation.

[5] GANS, Judith (2006), A Primer on U.S. Immigration in a Global Economy, University of Arizona: Udall Center for Studies in Public Policy.

[6] HUNTINGTON, Samuel P. (2004), Who Are We? The Challenges to America's National Identity, New York: Simon and Schuster. 
[7] JOHNSON, Chalmers (2004), The Sorrows of Empire: Militarism, Secrecy, and the End of the Republic, New York: Metropolitan Books.

[8] MAKLIN, Michelle (2002), How America Still Welcomes Terrorists, Criminals and Other Foreign Menaces to Our Shores: Washington D.C.: Regnery Publishing, Inc.

[9] MENDY, Louis (2015), Survivances de doctrine du puritanisme dans l'Amérique moderne, Paris : L'Harmattan.

[10] NGAI, Mae M. (2005), Impossible Subjects: Illegal Aliens and the Making of Modern America, Princeton, NJ: Princeton University Press.

[11] PORTES, Alejandro and STEPICK, Alex (1994), City on the Edge: The Transformation of Miami, Berkeley: University of California Press.

[12] SCHLESINGER, Arthur M. (1998), The Disuniting of America: Reflections on a Multicultural Society, New York: Norton.

\section{Webography}

[1] ADAMS, George Benton, "The United States and the Anglo-Saxon Future", Atlantic Monthly78 (1896), 35-45. In https://www.theatlantic.com. 24 Aug. 2020.

[2] FAIR (Federation for American Immigration Reform), "The United States is Already Overpopulated", September 2009, in http:/fairus.org/issue/population-environment/united-statesalready-overpopulated. 26 Aug. 2020.

[3] FISK, John, "Manifest Destiny", Project 2003, https://www.gutenberg.org/files/10112/10112.txt.

[4] FREEMAN, Joshua B., "Hardhats: Construction Workers, Manliness, and the 1970 Pro-War Demonstrations" Journal of Social History, Vol. 26, No. 4 (Summer, 1993), pp. 725-744 Published by: Oxford University Press http://www.jstor.org/stable/3788778. 27 Aug. 2020.

[5] KALLICK, David Dyssegaard et al., "Syrian Immigrants in the United States", Center for American Progress,

https://www.americanprogress.org/issues/immigration/reports/2016/12/13/294851/syrianimmigrants-in-the-united-states-a-receiving-community-for-todays-refugees/. 04 Sep. 2020.

[6] KENNEDY, John. F. (1964). Report to the American People on Civil Rights. Retrieved December 14, 2017, from https://www.jfklibrary.org/Research/Research-Aids/JFK-Speeches/CivilRightsRadio-and-Television-Report_19630611.aspx. 14 Sep. 2020.

[7] White Anglo-Saxon Protestant, in https://ipfs.io/ipfs/.../wiki/White_Anglo-Saxon_Protestant, 21 Aug. 2020. 